\title{
Klyngevejledning af specialestuderende
}

Janni Niclasen, psykolog, ph.d., lektor ved Center for Sundhedssamarbejde, Aarhus Universitet og adjunkt ved Institut for Psykologi, Københavns Universitet.

\section{Faglig artikel (bedømt af redaktionen)}

Universitetsvejledning har traditionelt voeret karakteriseret ved at finde sted $i$ "et lukket rum" som en dyadisk interaktion mellem en studerende og en vejleder. Inden for de senere år er der kommet mere fokus på klyngevejledning, defineret ved en vejleder, der superviserer foran en gruppe af studerende. Der er kun begrcenset med forskning om klyngevejledning, men et norsk studie har påpeget fordelene ved en kombineret effekt bestående af klyngevejledning i kombination med studenterkollokvier og individuel vejledning (Dysthe, Samara \& Westrheim, 2006). Formålet med indevorende projekt var at undersøge, hvorledes klyngevejledning optimalt set bør tage form i forbindelse med specialeskrivning. På baggrund af interviews med klyngedeltagerne blev det konkluderet, at det er essentielt, at der forventningsafstemmes inden forløbet påbegyndes, at strukturen for klyngen ekspliciteres for alle klyngedeltagere, samt at alle deltagere engagerer sig og overholder og efterlever reglerne og strukturen for klyngen. Derudover blev det konkluderet, at der som udgangspunkt kun bør tilbydes klyngevejledning, men at dette $i$ visse tilfoelde kan kombineres med korte individuelle vejledningsgange, hvis en studerende har brug for specifikke råd og vejledning. Derudover bør vejleder opfordre til, at de studerende mødes uden vejleder $i$ et uformelt forum mellem de enkelte vejledningsgange.

\section{Introduktion}

I modsætning til vejledning, udgør undervisning som fænomen en essentiel del af Universitetsloven (Ministeriet for Videnskab, Teknologi og Udvikling, 2014). Det fremgår for eksempel, at der skal finde dialog sted mellem universiteterne og aftagerpanelet for at sikre kvalitet og relevans for samfundet ved udvikling af nye undervisnings- og prøveformer (\$13a, stk. 2). Derudover omhandler $\$ 18$ i sin helhed forskellige aspekter af undervisning, inklusiv hvorledes den kvalitetssikres, tilrettelægges, gennemføres og udvikles.

Når det derimod kommer til vejledning, er der praktisk talt intet formaliseret i Universitetsloven. Det fremgår eksplicit, at der skal finde vejledning sted $\mathrm{i}$ forbindelse med ph.d.-forløb (\$16). Omvendt, når det kommer til vejledning på bachelor- og kandidatniveau, fremgår det blot, i forbindelse med specialer, at "studielederen godkender opgaveformulering og afleveringstidspunkt for kandidatspecialet samt i tilknytning hertil en plan for vejledningen af den studerende" (Ministeriet for Videnskab, Teknologi og Udvikling, 2014). Dette synes bemærkelsesværdigt, idet vejledning af de stude- 
rende reelt set burde udgøre en stor og yderst vigtig del af den undervisning, der samlet set finder sted på universiteterne.

\section{Individuel vejledning}

Denne markante forskel fra Ministeriets side for hhv. undervisning og vejledning afspejles ligeledes i, hvor meget forskningslitteratur der netop har haft fokus på undervisning og vejledning. I den forskningsbaserede litteratur har der været et enormt fokus på undervisning og undervisningsstile ( $f x$ Wichmann-Hansen, Mørcke \& Eika 2007; Nordentoft, Thomsen \& Wichmann-Hansen, 2013; Dahl, Dohn, Myong, Pless \& Thomsen, 2011; Jensen, 2014). Omvendt har vejledning ikke på samme måde tiltrukket sig forskernes opmærksomhed. Dette skyldes måske til dels, at vejledning ikke er en formaliseret del af Universitetsloven, men sikkert også, at vejledning traditionelt set har fundet sted "i et lukket rum" (Wichmann-Hansen, Mørcke \& Eika, 2007) og har været opfattet som et privat anliggende mellem én studerende og én vejleder. Individuel vejledning er karakteriseret ved en dyadisk interaktion mellem én enkelt studerende og én vejleder. Idet der som sagt kun findes begrænset forskning på området, ved vi faktisk kun ganske lidt om, hvad der karakteriserer god individuel vejledning. Et enkelt, omfattende systematisk review fokuserede på udgivne, empiriske studier med fokus på vejledning på universitetsniveau (Wichmann-Hansen, Mørcke \& Eika, 2007). Forfatterne søgte litteratur i danske, nordiske og internationale databaser. De identificerede på den baggrund 50 artikler omhandlende vejledning, der fordelte sig på 17 nordiske og 33 internationale studier. Forfatterne fandt, at studierne overvejende var baseret på selvrapporterede data, primært kvalitative interviews. De fandt, at studierne primært omhandlede vejledning på postgraduat niveau, samt at de oftest anlagde de studerendes perspektiv eller en kombination af et studenter-/vejlederperspektiv i studiet. Desuden viste analysen, at størstedelen af de 50 undersøgelser havde til formål at beskrive informanternes forventninger, holdninger og erfaringer med at indgå i en vejledningsrelation. Flere af studierne havde desuden fokus på, hvad der definerer en god vejleder. Samlet set blev det konkluderet, at det var altafgørende, at vejlederen var tilgængelig for vejledning (fysisk såvel som mentalt), og at denne havde læst de studerendes tekstoplæg grundigt og gav konstruktiv feedback herpå. Kun sekundært lagde de studerende vægt på, at vejleder havde faglig indsigt i deres forskningsfelt. Desuden blev det konkluderet, at en vellykket vejledningsproces afhang af en god relation mellem den studerende og vejlederen. Slutteligt var det interessant at bemærke, at kun to ud af de 50 studier beskæftigede sig med vejledning i grupper, resten havde fokus på individuel vejledning (Samara, 2007; Dysthe, Samara \& Westrheim, 2006).

\section{Klyngevejledning}

Ovenstående systematiske litteraturgennemgang blev udført i 2007 og inkluderede to empirisk baserede artikler om vejledning i klynger. Ved at foretage en systematisk 
litteratursøgning i juni 2015 fremkom det, at der siden er udkommet yderligere tre videnskabelige artikler (Samara, 2007; Nordentoft, Thomsen \& Wichmann-Hansen, 2013; Wichmann-Hansen, Thomsen \& Nordentoft, 2015), et konferencepapir (Dahl et al., 2011) samt en bog om klyngevejledning (Jensen, 2015).

Klyngevejledning er karakteriseret ved, at en enkelt vejleder superviserer foran en gruppe af studerende. En klynge kan bestå af mellem 2 og 7 studerende men vil typisk indeholde 4-6 studerende (Jensen, 2015). Specifikt er klyngevejledning, eller kollektiv vejledning som det også kan betegnes, kendetegnet ved at være vejledning, hvor en gruppe af studerende, der har samme vejleder, arbejder med hver deres projekt, men modtager deres vejledning foran klyngen. Dette i modsætning til gruppevejledning, der er defineret ved, at flere studerende arbejder sammen om et fælles projekt, hvortil de har knyttet én enkelt vejleder (Dahl et al., 2011).

Klyngevejledning er som sagt et relativt nyt fænomen, og det er altså begrænset hvor meget empirisk-baseret litteratur, der har fokus herpå. Dahl, et al. (2011) præsenterer i deres konferencepapir data fra en mindre survey baseret på interviews med DPU-ansatte, der har gjort sig erfaringer med at vejlede flere studerende på en gang. Formålet med undersøgelsen var, at få indsigt i vejledernes erfaringer med og begrundelser for at vejlede i klynger. Interviewpersonerne fremhævede navnlig den kollektive vejledningsform som mere dialogbaseret, hvor de studerende lærer ved at lytte samt ved at give feedback til hinanden. Dette øger de studerendes videnskabelige argumentationsform, hvilke også fremhæves som et argument for klyngevejledning i andre dele af litteraturen (fx Nordentoft, Thomsen \& Wichmann-Hansen, 2013; Dysthe, Samara \& Westrheim, 2006). Derudover fremhævede forfatterne fordelene ved, at man i kollektiv vejledning kun behøver at sige formalia omkring akademisk skrivning én gang, hvilket giver mere tid til at gå i dybden med andre, fagligt relaterede aspekter af vejledningen.

I en norsk undersøgelse analyserede forskerne på den samlede effekt af en kombineret model bestående af gruppevejledning (to vejledere og en gruppe af studerende), kollokvium (hvor de studerende mødtes uden vejledere) og individuel vejledning (et mere klassisk møde mellem én vejleder og én studerende) (Dysthe, Samara \& Westrheim, 2006). Forfatterne konkluderede, at de tre fora komplementerede hinanden godt, og at en kombineret model, der inkluderede triaden af mødefora, var at foretrække. I studenterkollokvierne fandt de studerende den personlige støtte, de efterlyste, i klyngevejledningen fik de studerende feedback på deres tekster fra hele gruppen, mens de i den individuelle vejledning kunne hente specifikke råd og vejledning. Forfatterne konkluderede endvidere, at for at klyngevejledning skal fungere, er det vigtigt, at gruppen mødes jævnligt, at deltagerne føler sig gensidigt forpligtiget over for hinanden, og at der fra vejleders side opstilles en gennemsigtig struktur med klare regler. 


\section{Indeværende projekt}

\section{Klyngevejledning - erfaringer fra egen praksis}

Med afsæt i ovenstående erfaringer fra den empirisk-baserede litteratur om klyngevejledning besluttede jeg i foråret 2015 at klyngevejlede en gruppe bestående af to specialestuderende med henblik på at udvikle en model for, hvordan klyngevejledning kan tage form i forbindelse med vejledning af specialestuderende. Specifikt var formålet at undersøge: 1) hvilke aspekter af klyngestrukturen der er afgørende for en vellykket klynge?, 2) om der udelukkende skal tilbydes klyngevejledning, eller om dette skal kombineres med individuel vejledning?, og 3) hvorvidt de studerende skal opfordres til at mødes i studenterkollokvier mellem de enkelte klyngevejledningsgange?

\section{Klyngen og de fysiske rammer}

Klyngen bestod af to studerende, som begge aktivt havde valgt klyngen til. De henvendte sig til vejleder på baggrund af et opslag, hvor der blev annonceret efter specialestuderende, som ønskede at indgå i klyngen. Inden de skrev specialekontrakten under, læste de vejleders vejledningsprofil. Derudover blev rammerne for klyngen ekspliciteret for dem, og de accepterede de formelle og strukturelle rammer for klyngen.

Begge studerende blev tilbudt en specialeplads i nærheden af vejleders kontor. De studerende skrev to indholdsmæssigt meget forskellige projekter uden nogen form for fagligt overlap. Dog baserede begge projekter sig på to kvalitative interviews.

\section{Strukturen for klyngevejledningen}

Ved den første egentlige klyngevejledning holdt vejleder et oplæg bestående af to dele. Første del havde fokus på "det gode speciale" og præsenterede generelle ideer om det gode speciale, inklusiv metakommunikation, struktur, opbygning og studieordning. Anden del fokuserede på strukturen for klyngevejledningen. Her blev vigtigheden af, at aftaler overholdes, respekt og fortrolighed i klyngen, ekspliciteret.

Derudover blev de studerende præsenteret for de specifikke principper og den opbygning, der dannede udgangspunkt for de enkelte klyngevejledninger. Vejledningen startede med, at en af de studerende gik i gang med at præsentere sit tekstudkast med udgangspunkt i følgende tre spørgsmål: 1) hvad er jeg i gang med?, 2) hvad går godt? og 3) hvad har jeg af spørgsmål/hvad kan jeg ikke forstå? Herefter gav den anden studerende feedback med udgangspunkt i de tre spørgsmål: 1) tre ting jeg godt kan lide, 2) tre ting jeg gerne vil høre mere om, og 3) evt. noget jeg ikke forstår. Vejleder gav altid sin feedback til sidst med udgangspunkt i de samme tre spørgsmål.

Afslutningsvis blev ordet givet til oplægsholderen med en afrundende snak om den feedback denne havde modtaget, om der var dukket yderligere spørgsmål op i for- 
bindelse med den modtagne feedback samt en afrundende snak om, hvorledes oplægsholderen kunne komme videre med projektet. Principperne for og opbygningen af strukturen tog udgangspunkt i et forslag til klyngevejledning beskrevet i Jensen (2015).

Vejledningen tog udgangspunkt i tekstudkast på typisk 5-8 sider, som de studerende havde rundsendt inden vejledningen. For at sikre, at der blev givet lige meget tid til begge studerendes projekter, tog vejleder tid.

Som afslutning på vejledningen blev der fundet en dato for næste vejledningsmøde, samt et tidspunkt for, hvornår de studerende senest skulle sende deres tekster til næste vejledningsgang. Ambitionen var, at de studerende sendte så sent som muligt, hvilket i de fleste tilfælde betød, at de emailede deres tekster inden kl. 8 om morgenen, når der var vejledning kl. 13.

\section{Ekstra individuelle vejledningsgange}

I undersøgelsen af Dysthe, Samara \& Westrheim (2006) præsenteret ovenfor understreges vigtigheden af en samlet model bestående af gruppevejledning, kollokvium samt individuel vejledning. I den individuelle vejledning kan de studerende hente specifikke råd og vejledning. I indeværende projekt blev der kun tilbudt korte, individuelle vejledningsgange af ca. 5-10 minutters varighed, hvis vejleder vurderede, at en studerende havde brug for individuelle råd og vejledning for at kunne komme videre med projektet. Individuel vejledning lå typisk 2-4 dage efter klyngevejledningen.

\section{Studenterkollokvium}

Med udgangspunkt i den norske undersøgelse (Dysthe, Samara \& Westrheim, 2006) foreslog vejleder endvidere, at de studerende med fordel kunne mødes fast (eksempelvis en gang om ugen) mellem de enkelte klyngevejledningsgange for at opnå personlig støtte fra klyngen.

\section{Resultater og diskussion}

Nedenfor præsenteres erfaringerne fra forløbet med vejledning af specialestuderende i klynger.

Evalueringen baserer sig på udtalelser fra de studerende foretaget dels midt i vejledningsforløbet og dels fra den afsluttende evaluering foretaget efter sidste vejledningsgang.

\section{Hvad fungerede godt?}

\section{Strukturen for vejledningen}

På baggrund af indeværende erfaringer og interviews med de studerende anbefales det, at klyngevejledning bygges op omkring en rigid, genkendelig struktur, samt at der forventningsafstemmes, inden vejledningsforløbet påbegyndes. De studerende i 
indeværende klynge var enige om, at den rigide struktur, der dannede grundlag for vejledningen, fungerede rigtig godt og rammesættende. De nævnte yderligere genkendeligheden og den faste struktur som noget positivt. Ved at der blev forventningsafstemt inden vejledningsforløbet blev påbegyndt, vidste de studerende, hvad de gik ind til. Endvidere var de studerende blevet bedt om at læse vejlederprofilen og om at tænke over, hvilke forventninger de havde til vejleder, inden de startede forløbet. I litteraturen peges der på, at der kan være store forskelle mellem, hvad studerende og vejledere har af forventninger til eksempelvis fordelingen af ansvar samt til støtte og styring i forbindelse med et speciale (Jensen 1992; Dahl et al, 2011; Wichmann-Hansen, Mørcke \& Eika, 2007). Ved at forventningsafstemme inden forløbet startede og ved at eksplicitere rammerne for vejledningen, var dette blevet foregrebet.

Derudover er der store forskelle på, hvilken rolle vejledere påtager sig. Et centralt studie af Ylijoki (2001) konkluderede, at vejledere falder inden for en af tre kategorier: akademikeren, konsulenten eller moren. I indeværende projekt påtog jeg mig primært rollen som konsulent. Men fordi dette netop var blevet afstemt inden vejledningsforløbet blev påbegyndt, synes det heller ikke at påvirke vejledningsforløbet i en negativ retning, da de studerende var forberedt herpå. Hvis der er uoverensstemmelser mellem den rolle vejlederen tager og de forventninger, den studerende har til vejleder, vil vejledningsforløbet være præget heraf. Ydermere har de studerende ofte urealistiske forventninger til mængden af tid, vejleder kan bruge på den enkelte studerende (Harboe, 2005). Ved at eksplicitere rammerne for vejledning og forventningsafstemme inden starten af vejledningsforløbet forebygges dette.

Begge studerende nævnte, at det var helt essentielt, at klyngen var præget af åbenhed, ærlighed og fortrolighed. De var glade for, at de som studerende startede med at give feedback, og at vejleder gav feedback til sidst. De satte endvidere pris på, at de kunne sende deres tekster relativt kort tid før klyngevejledningen. Ligeledes nævnte de, at det var spændende og givtigt at få indblik i hinandens projekter til trods for, at de skrev to fagligt vidt forskellige projekter. Dette tyder altså på, at det ikke er det faglige indhold i specialeprojekterne per se, der afgør, hvorvidt de studerende kan få gavn af klyngen. Med andre ord bør indholdet af større opgaver altså ikke være det, der skal være bestemmende for sammensætningen af studerende til de enkelte klynger.

Samlet set kan det konkluderes, at det er essentielt for en velfungerende klynge, at der forventningsafstemmes, inden forløbet påbegyndes, og at strukturen for klyngen ekspliciteres for alle klyngedeltagere. Det er også essentielt at alle deltagere engagerer sig i og overholder og efterlever reglerne og strukturen for klyngen. Vejleders samt de studerendes roller og forpligtelser over for hinanden skal ekspliciteres. Rammesætning bør derfor udgøre en betragtelig del af første klyngevejlednings- 
gang. Dernæst er fortrolighed mellem klyngedeltagerne afgørende for en velfungerende klynge. Af mindre væsentlig karakter for de studerendes udbytte af klyngen er det faglige indhold af deres projekter.

\section{Ekstra individuelle vejledningsgange}

Som udgangspunkt for indeværende projekt blev de studerende ikke tilbudt individuel vejledning men udelukkende vejledning i klynger. I studiet af Dysthe, Samara \& Westrheim (2006) blev en kombination af individuel og klyngevejledning foreslået, hvor formålet med individuel vejledning er, at de studerende har et forum, hvor de kan hente specifikke råd og vejledning. Med udgangspunkt heri blev der tilbudt ekstra, individuel vejledning, hvis vejleder vurderede, at en studerende havde brug for dette. I indeværende projekt fik en af de studerende individuel vejledning to gange, ca. 3-4 arbejdsdage efter klyngevejledningen. Det betød, at den studerende på den måde kom "hurtigt tilbage på sporet" og kunne arbejde videre med projektet. Man kan med andre ord sige, at specialeprocessen blev speedet markant op ved at indlægge sådanne små, individuelle vejledningsmøder. De studerende fremhævede også, at det fungerede godt med de ekstra individuelle vejledningsgange, der blev indlagt efter behov.

\section{Studenterkollokvium eller kontorfaellesskab?}

De studerende var enige om, at det havde stor betydning for deres specialeproces, at de sad sammen og kunne sparre med hinanden på daglig basis. Effekten af at have et kontorfællesskab kan sidestilles med effekten af den personlige støtte, de studerende henter i studenterkollokvierne som beskrevet i Dysthe, Samara \& Westrheim (2006). Noget tyder altså på, at en vigtig del af en god specialeproces er, at de studerende har mulighed for at mødes med andre studerende i et uformelt forum, hvor de kan opnå personlig støtte, dele frustrationer over specialeprocessen og diskutere idéer, inden disse diskuteres i klyngen/med vejleder. Det er vejleders ansvar at italesætte dette for de studerende, som deltager i klyngevejledning.

\section{Feedback fra andre end blot vejleder}

Begge studerende var enige i, at det var meget brugbart at få feedback og input fra flere end blot vejleder. I den systematiske litteraturgennemgang af WichmannHansen, Mørcke \& Eika (2007) fremgik det, at det, de fleste studerende lægger vægt på hos en god vejleder, er, at vejlederen er tilgængelig for vejledning (fysisk såvel som mentalt), samt at vejlederen har læst deres tekstoplæg grundigt og giver konstruktiv feedback herpå. Kun sekundært lægger de studerende vægt på, at vejleder har faglig indsigt i deres forskningsfelt. I indeværende projekt mødte begge studerende (samt vejleder) velforberedte og engagerede op og fik altså konstruktiv feedback fra medstuderende såvel som fra vejleder. Dette nævnte begge studerende som et positivt og givtigt aspekt ved klyngen. På den baggrund kan det konkluderes, 
at de studerende altså drager nytte af klyngen, netop fordi det ikke blot er vejleder men også klyngen, der er tilgængelige og velforberedte kilder til konstruktiv feedback på deres tekststykker. Fordi de studerende skrev indholdsmæssigt meget forskellige specialer, og de altså stadig fik meget konstruktiv feedback med på vejen, kan det altså konkluderes, at specifik faglig indsigt hos den der giver feedback er af sekundær betydning.

\section{Hvad kunne forbedres?}

Som del af evalueringen blev de studerende specifikt bedt om at komme med konkrete forslag til ændringer til klyngen. I den forbindelse efterlyste de flere oplæg fra vejleder, eksempelvis omkring hvordan man skriver en god analyse eller diskussion. Dette kan med fordel implementeres fremadrettet, da en af fordelene ved klynger netop er, at man har mulighed for at gå mere i dybden med eksempelvis konkrete bud på, hvordan den gode analyse eller diskussion bygges op og skrives.

\section{Konklusion}

På baggrund af ovenstående kan det konkluderes, at der, sammenlignet med individuel vejledning, er mange fordele ved at vejlede i klynger. Den første og måske væsentligste fordel er, at det optimerer de studerendes læring - de får skrevet nogle bedre opgaver og de lærer at give og modtage feedback inden for fastsatte rammer. Det er fascinerende, som vejleder at opleve, at man kan opstille rammer for vejledning, der bevirker, at de studerende giver konstruktiv og værdifuld feedback til hinanden. Sat lidt på spidsen kan man sige, at rammerne til tider nærmest "overflødiggjorde" vejleder, fordi de studerende blev rigtigt gode til at give hinanden konstruktiv og brugbar feedback. Eksempelvis havde de studerende ofte de samme kommentarer som vejleder. Derudover diskuterede de studerende ofte indbyrdes et givent tekststykke uden indblanding af vejleder - om end selvfølgelig under kyndig supervision af vejleder, hvis der blev behov for dette. Man kan sige, at de studerende opnåede kompetencer $\mathrm{i}$ forhold til at give og modtage feedback - kompetencer som er yderst relevante for aftagerpanelet, altså arbejdsmarkedet for psykologer. De fik med andre ord udviklet deres videnskabelige argumentationsform.

Ud fra litteraturen er der endvidere noget, der tyder på, at de studerende afleverer deres specialer hurtigere, hvilket selvsagt er en fordel jf. Fremdriftsreformen. Da indeværende projekt baserer sig på en klynge med kun to studerende, er det selvfølgelig ikke muligt at analysere på dette parameter. Dog var fornemmelsen, at de studerende blev holdt til ilden qua klyngen og derfor kontinuerligt arbejdede med deres projekter uden eksempelvis at ende i specialesumpen. Ligeledes diskuteres det i litteraturen, hvorvidt de studerende får skrevet bedre specialer. Hvis dette er tilfældet, kan det skyldes, at de modtager feedback fra flere end blot vejleder, men også at de selv får gavn af at læse andre studerendes tekststykker og give feedback til deres medstuderende. Ved at skulle tage stilling til, hvad der fungerer og ikke fun- 
gerer i medstuderendes tekststykker, får de skærpet deres opmærksomhed på, hvad der virker godt i deres eget speciale.

\section{Konkretet anbefalinger til implementering af klyngevejledning}

Med udgangspunkt i ovenfor beskrevne erfaringer kan det undre, at vejledning ikke nævnes eksplicit i Universitetsloven. Det synes indlysende at tilføje og eksplicitere vejledning (snarere end blot undervisnings- og prøveformer) til Universitetsloven. Derudover kan det undre, at klyngevejledning ikke fremstår som en integreret del af vejledning på landets højere læreranstalter. Med udgangspunkt i ovenstående analyse foreslås det derfor, at klyngevejledning i langt højere grad implementeres og anvendes som primær specialevejledningsform på de danske universiteter.

Hvilke aspekter af klyngestrukturen er afgørende for en vellykket klynge?

Det blev konkluderet, at det er altafgørende, at forventningsafstemme inden opstart af klyngen med hver enkelt studerende. Derudover er det helt essentielt, at der opstilles klare regler for klyngen ved den første klyngevejledningsgang. Den første vejledningsgang har altså en helt central betydning for det videre forløb. Omvendt har det ingen betydning, at de studerende skriver fagligt meget forskellige projekter.

Skal der udelukkende tilbydes klyngevejledning eller skal dette kombineres med individuel vejledning?

På baggrund af ovenstående erfaringer foreslås det, at de studerende som udgangspunkt kun skal tilbydes klyngevejledning. Individuel vejledning bør kun tilbydes de studerende, hvor det at skulle vente med vejledning til næste klyngevejledning vil forsinke deres proces, eller i de tilfælde, hvor de studerende har brug for specifikke råd og vejledning.

Skal de studerende opfordres til at mødes i studenterkollokvier mellem de enkelte klyngevejledningsgange?

Ja, hvis ikke de studerende har et kontorfællesskab eller lignende til rådighed, skal de opfordres til at mødes i studenterkollokvier imellem de enkelte klyngevejledningsgange. Formålet med disse fora er, at de studerende kan få personlig støtte og indledningsvis drøfte faglige idéer, de måtte have, inden disse diskuteres med vejleder. Det er vejleders ansvar at italesætte og initiere dette ved det første klyngevejledningsmøde. Det er endvidere vejleders ansvar at informere de studerende om fordelene ved at mødes fast i sådanne studenterkollokvier.

Janni Niclasen er lektor på Center for Sundhedssamarbejde, Aarhus Universitet. Janni Niclasen forsker primaert inden for børne- og ungeområdet. Hun underviser i epidemiologi, forskningsmetode, psykometri, sundhedspsykologi, udviklingspsykologi og paedagogisk psykologi. Janni Niclasen har altid voeret meget glad for vejledning af studerende men har haft en oplevelse af at bruge meget tid på gentagelse af eksempelvis formalia. Derfor 
valgte hun, som del af hendes adjunktpoedagogikum, at fokusere på klyngevejledning og på, hvorledes dette fremadrettet optimalt set kan implementeres i forbindelse med specialevejledning.

\section{Litteratur}

Dahl, K., Dohn, N. B., Myong, L., Pless, M. \& Thomsen, R. (2011). Didaktiske udfordringer i kollektiv akademisk vejledning - set fra et vejlederperspektiv. Universitetspædagogisk kursus for adjunkter, Aarhus Universitet.

Dysthe, O., Samara, A. \& Westrheim, K. (2006). Multivoiced supervision of Master's students: a case study of alternative supervision practices in higher education. Studies in Higher Education, 31(3), 299-318.

Harboe, T. (2005). Akademisk opgavevejledning: en handlingsorienteret analyse af 51 udvalgte klagesager. Det Samfundsvidenskabelige Fakultet, Københavns Universitet.

Jensen, H. N. (1992). Specialevejledning: resultater af en undersøgelse blandt vejledere og vejledte. Institut for Statskundskab, Københavns Universitet.

Jensen, H. N. (2008). Ja tak til mere kollektiv opgave- og skrivevejledning! Dansk Universitetspoedagogisk Tidsskrift, 3(6), 15-20.

Jensen, H. N. (2014). Feedback i klynger. Institut for Statskundskab, Københavns Universitet.

Jensen, H. N. (2015). Opgave- og skrivevejledning i klynger. Håndbog for undervisere og vejledere på videregående uddannelser. Frederiksberg: Samfundslitteratur.

Ministeriet for Videnskab, Teknologi og Udvikling (2014). Universitets/oven. https://www.retsinformation.dk/Forms/r0710.aspx?id=168797. Ministeriet for Videnskab, Teknologi og Udvikling.

Nordentoft, H. M., Thomsen, R. \& Wichmann-Hansen, G. (2013). Collective academic supervision: a model for participation and learning in higher education. Higher Education, 65(5), 581-593.

Samara, A. (2007). Group supervision in graduate education: a process of supervision skill development and text improvement. Higher Education Research and Development, 25(2), 115-129.

Ylijoki, O. H. (2001). Master's thesis. Writing from a narrative approach. Studies in Higher Education, 26(1), 21-34.

Wichmann-Hansen, G., Mørcke, A. M. \& Eika, B. (2007). Hvad findes der af litteratur om vejledning? - Litteratursøgning med fokus på publicerede, evidensbaserede studier. Dansk Universitetspaedagogisk Netvoerk, 3, 11-19.

Wichmann-Hansen, G., Thomsen, R. \& Nordentoft, H. M. (2015). Challenges in collective academic supervision: supervisors' experiences from a Master programme in guidance and counselling. Higher Education, 70(1), 19-33. 